\title{
Distribution of Design: The Rayed Circle
}

\author{
Duncan P. McKinnon \\ University of Central Arkansas
}

Follow this and additional works at: https://scholarworks.sfasu.edu/ita

Part of the American Material Culture Commons, Archaeological Anthropology Commons, Environmental Studies Commons, Other American Studies Commons, Other Arts and Humanities Commons, Other History of Art, Architecture, and Archaeology Commons, and the United States History Commons

Tell us how this article helped you.

This Article is brought to you for free and open access by the Center for Regional Heritage Research at SFA ScholarWorks. It has been accepted for inclusion in Index of Texas Archaeology: Open Access Gray Literature from the Lone Star State by an authorized editor of SFA ScholarWorks. For more information, please contact cdsscholarworks@sfasu.edu. 


\section{Distribution of Design: The Rayed Circle}

Creative Commons License

(c) $)$ (i) @

This work is licensed under a Creative Commons Attribution-NonCommercial 4.0 International License 


\section{Distribution of Design: The Rayed Circle}

\section{Duncan P. McKinnon}

The importance of the use of a Geographic Information System (GIS) in archaeological applications has been demonstrated previously (Allen et al. 1990; Hodder and Orton 1976; Kvamme 1999, 2007; Neubauer 2004; Wheatley and Gillings 2002). The value of using a GIS approach is an ability to conduct multivariate spatial analyses in order to visualize complex social relationships, interactions, and distributions across a broad cultural landscape (Anselin 2005; Maguire 2005). Within Caddo archaeology, the utilization of GIS functionality to explore spatial phenomenon has been employed in a variety of ways, such as site organization and interaction (Brooks 2012; Lockhart 2010, 2012; Vogel 2012), material distribution and exchange (McKinnon 2011, 2015), and environmental modeling and landscape reconstruction (Lockhart 2007; Williams 2007), to name a few. The following report adds to the growing list of GIS-based case studies in Caddo archaeology with preliminary results of an on-going project evaluating the distribution of visual imagery depicted on a select corpus of whole Caddo ceramic vessels.

Broadly, this project provides a foundational framework containing a variable series of attributes from over 4,000 Caddo ceramic vessels that can be compared to a variety of cultural and environmental datasets (Figure 1). While 4,000 vessels are certainly numerous, this is far from a complete sample. However, the 4,000 Caddo vessels that define the current database provide a structure for evaluating the distribution of stylistic and formalized attributes, fully acknowledging that sampling and documentation biases do exist. The voluminous amount of site publications, inventories, and regional summaries has yet to be fully inventoried, and there will never be a complete set of data. In other words, the database is, and will always be, a fragmented representation of the full extent of ceramic expressions across time and space (Hodder and Orton 1976:20-29; Jones 2002:41-46). As such, this project is a continuous work in progress and a start toward a larger goal of capturing and recording attributes associated with thousands of vessels from Caddo and neighboring archaeological sites. This developing effort offers an opportunity to visualize the spatial relationships of select attributes across the landscape and facilitate a forum for expanding, as well as refining, questions related to Caddo trade, interaction, and distribution of material expressions associated with prehistoric occupants of the Caddo Archaeological Area (see Perttula 1992; Girard et al. 2014).

The origin of this larger project began as an exploration in the efficacy of using a GIS to map the distribution and spatial relationship of 284 vessels of a specific Caddo vessel type, Foster Trailed-Incised (McKinnon 2011). The study proved to be informative in the mapping and identification of suggested cluster areas containing high occurrences of the Foster Trailed-Incised type and possible spatial outliers (using spatial statistics) that met the criteria for inclusion in the type (see Suhm et al. 1954; Schambach and Miller 1984). While the initial examination was not a complete representation of Foster Trailed-Incised vessels, results demonstrate that a GIS-based distributional approach is a productive method to visualize areas of cultural influence across a landscape using specific artifact attributes to identify possible statistical outliers. Outliers to a spatial pattern can then be examined and re-examined as additional ceramics are added to the database and the spatial pattern is expanded or modified (Genton 2001; Shekhar et al. 2003). In this context, outliers are important in that they offer consideration for potential cultural and economic interaction and exchange with neighboring groups that can be evaluated further as additional data are included and the analysis expanded (see also Girard et al. 2014). 


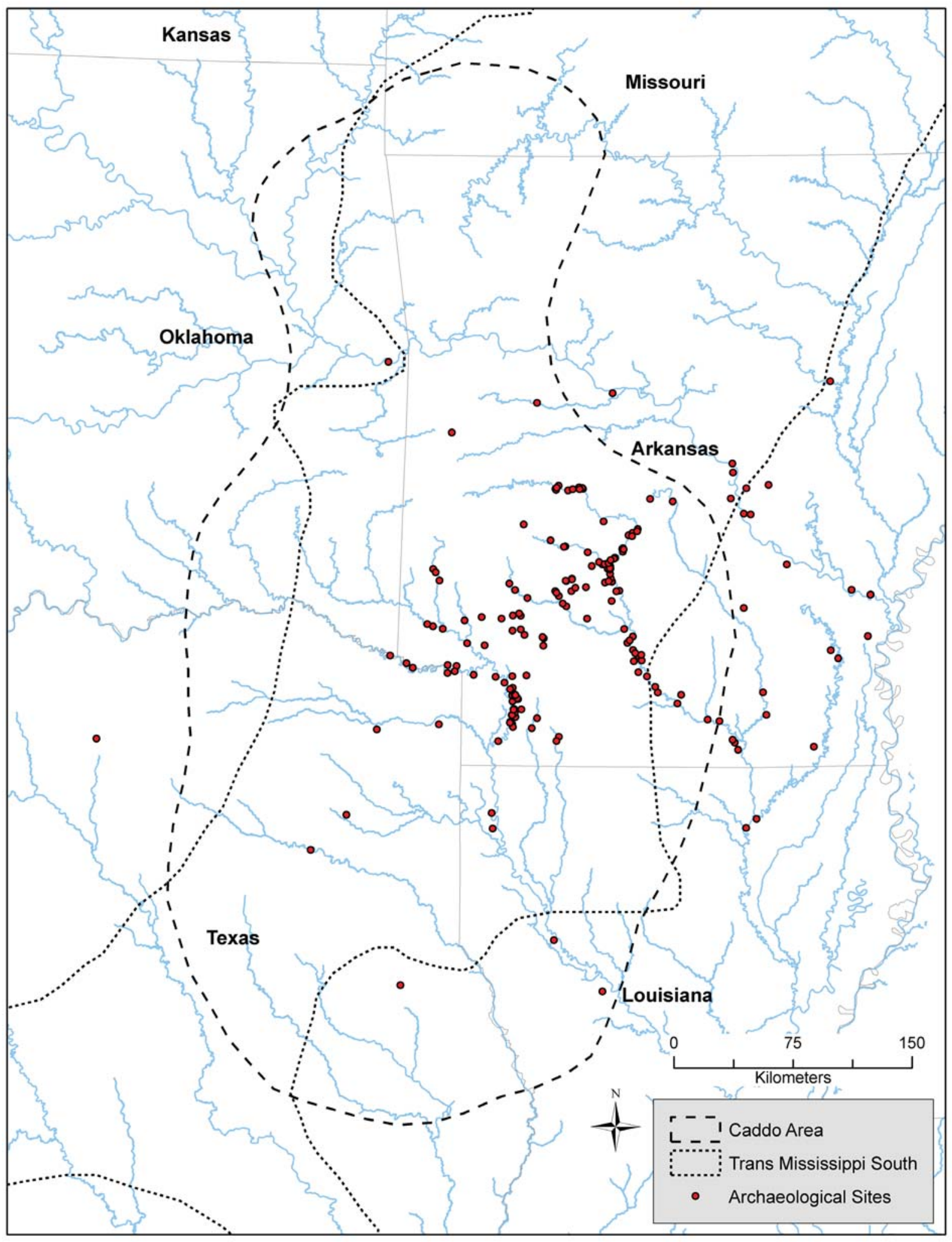

Figure 1. The distribution of archaeological sites within the current GIS ceramic distribution database. 
As a first case study, the initial Foster Trailed-Incised examination provided the necessary methodology to enlarge the GIS database in terms of the overall number of whole Caddo ceramic vessels and to expand the analysis to examine additional attributes that can be evaluated spatially. What follows is a presentation of a motif-based distribution analysis, a summary of initial findings and implications, and important considerations as this project proceeds.

\section{Methodology}

At present, the GIS database contains 4199 whole vessels from sites in Arkansas, Louisiana, Oklahoma, and Texas, although the database is currently biased toward Arkansas sites and locales (see Figure 1). This is because most of the vessels in the current database were originally photographed from numerous private collections around Arkansas in the 1960s, 70s, and 80s by several Arkansas Archeological Survey (AAS) station archaeologists, station assistants, and students. Several important collections are included, such as those of Mark R. Harrington (National Museum of American Indian; see also Harrington 1920), Thomas L. Hodges (Joint Educational Consortium; see also Early 1986), Vere Huddleston (Henderson State University), Judge Henry J. Lemley (Gilcrease Museum), and numerous others (Combs, Barnes, Birch, Blackwell, Blevins, Bryant, Jones, Chance, Durham, Figley, Franks, Franz, Furr, Kitchens, McClendon, McVay, Phillips, Redmond, Short, Shurtleff, Sibert, Sullivan, and White-Franco, to name a few). Also included are some vessels documented from a few seminal publications (for example, Bohannon 1973; Moore 1912; Webb 1959; see also Gregory 1980; Weinstein et al. 2003), although many publications are yet to be included. The vessel photographs were attached to orange index cards that have been referred to colloquially as the "analog database". Where information is available and noted, cards contain a black and white photograph of the vessel, site trinomial, collector information, ceramic attributes and observations (such as temper), and intrasite provenience information (burial numbers, etc.). Dr. Frank F. Schambach originally organized the photo cards during his tenure as station archaeologist at the AAS station in Magnolia, Arkansas. Recently, Dr. Schambach and student workers at Southern Arkansas University (SAU) in Magnolia scanned the cards into digitized form and I entered the attributes into a GIS database.

As stated, many of the ceramics in the current database are situated within Arkansas (see Figure 1). Of the current total, 580 (13 percent) have no provenience information and 220 ( 5 percent) contain site names with no accompanying trinomial where corresponding site names are not listed in the Automated Management of Archeological Site Data in Arkansas (AMASDA) database. Many of these unknown sites are likely regional vernacular names or perhaps previous landowner names not associated with current landowners. In some instances, a site trinomial provides county information but the specific site geographic location (UTM coordinate) is not recorded in AMASDA. This is primarily because numerous sites have been destroyed as a result of river meandering prior to their addition into the statewide repository. The exact locations of these former sites are unknown.

Removing these vessels from the corpus (given that they cannot be evaluated spatially), the database includes 3399 whole ceramic vessels. The current database contains ceramics from 187 archaeological sites in 36 counties (Arkansas, Oklahoma, and Texas) and 5 parishes (Louisiana). Sites containing the highest representation of ceramics include some recognizable sites in southwest Arkansas, such as Battle Mound (3LA1; McKinnon 2013), Mineral Springs (3HO1; Bohannon 1973), Washington Mounds (3HE35; Harrington 1920), Flowers (3HE37; Harrington 1920), Bowman (3LR50; Hoffman 1970), East (3CL21; Early 2002), Hayes (3CL6; Weber 1971), and Haley (3MI1; Hoffman 1970), and many other smaller sites. These larger sites are familiar and recognizable because of the research (although limited with some) and publications associated with them. Certainly, these do not represent the full suite of sites across the Caddo landscape and, as such, adds another level of biases that is inherent in archaeological survey methods, history of explorations and site accessibility, sampling selection, and issues with bounded areas as "sites" in contrast to a fully utilized landscape (Banning 2002; Dunnell and Dancy 1983; Hodder and Orton 1976). Furthermore, as this is a preliminary report of a second case study, the accuracy of metadata recorded on the cards and ceramic-site associations is ongoing. 


\section{Rayed Circle Motif}

In this second GIS ceramic database case study, the rayed circle motif was selected to examine spatial distributions and possible relationships. The rayed circle motif is defined in the Phillips and Brown Glossary of Motifs as a type of motif present on Spiro engraved shell cups (Phillips and Brown 1978:155). The motif is considered an elaboration on the barred oval motif where "rays or scallops" are added to a half oval containing two or more concentric lines (Phillips and Brown: Plate 36). In the context of this analysis, the rayed circle motif is used to apply to similar representations on ceramic vessels containing a series of concentric circles with one or more containing ray-like tics emanating from the center of the motif. The application is both engraved and incised. Some Caddo ceramic equivalents are Belcher Engraved vessels, where a series of concentric circles surrounds a "flower or star-like" element in the center (Suhm et al. 1954:244), Avery Engraved, where concentric semicircles contain ticked lines (Suhm et al. 1954:236), and Ripley Engraved, where concentric circles have "ticking or pendant triangles on lines" (Suhm et al. 1954:346). A more abstract representation is with Hempstead Engraved vessels where concentric circles are situated around the rim of bowls or the neck of bottles and contain "hatched or cross-hatched triangles" that point downward (Suhm et al. 1954:292).

Here, I introduce and distinguish two varieties of the rayed circle motif by first defining their parameters and criteria for inclusion in each variety. This is followed by an evaluation of the spatial distribution of each motif variety independently, and concluding with an observation on the distributional relationship between the two varieties.

\section{Rayed Circle Burst Motif}

What I define as the rayed circle "burst" variety is the most definitive of the rayed circle motifs.

The defining criterion is the presence of a central element, or burst, as a circle containing a series of small triangles or rays emanating outward from the center in a seemingly rotational movement (Figure 2a). The presence of at least one burst defines the motif, although variability is present with multiple bursts organized symmetrically with two or four on opposing sides. The burst motif is located on the body of the vessel where most ceramics in the corpus are bottle in form.
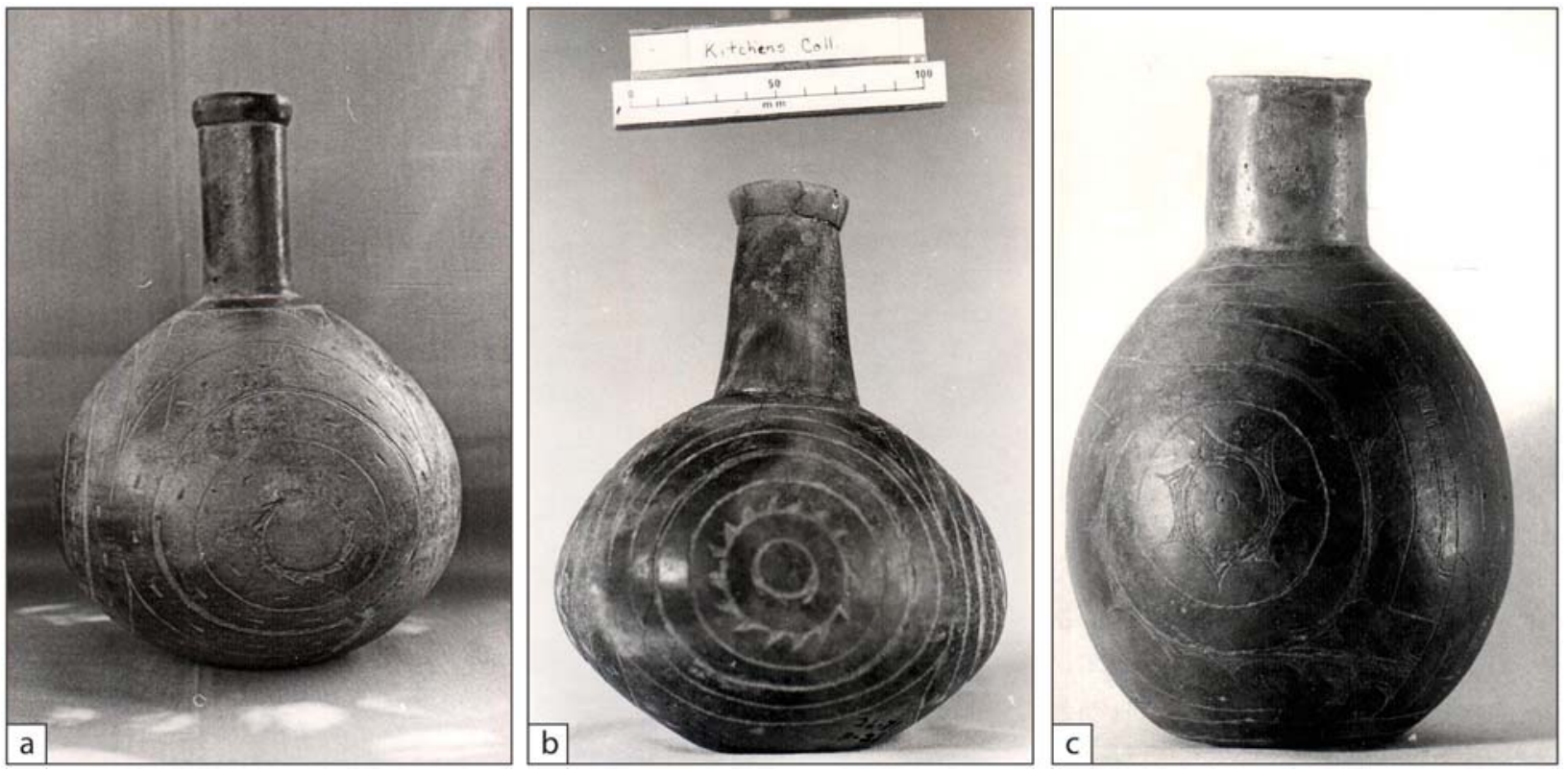

Figure 2. Examples of the Rayed Circle Burst motif (a) a bottle from Battle Mound (3LA1), AAS\# 714111; (b) a bottle from Cryer Field (3LA35), AAS\# 793229; (c) a bottle from Mineral Springs (3H01), AAS\# 651001. Images used with the permission of the Arkansas Archeological Survey. 

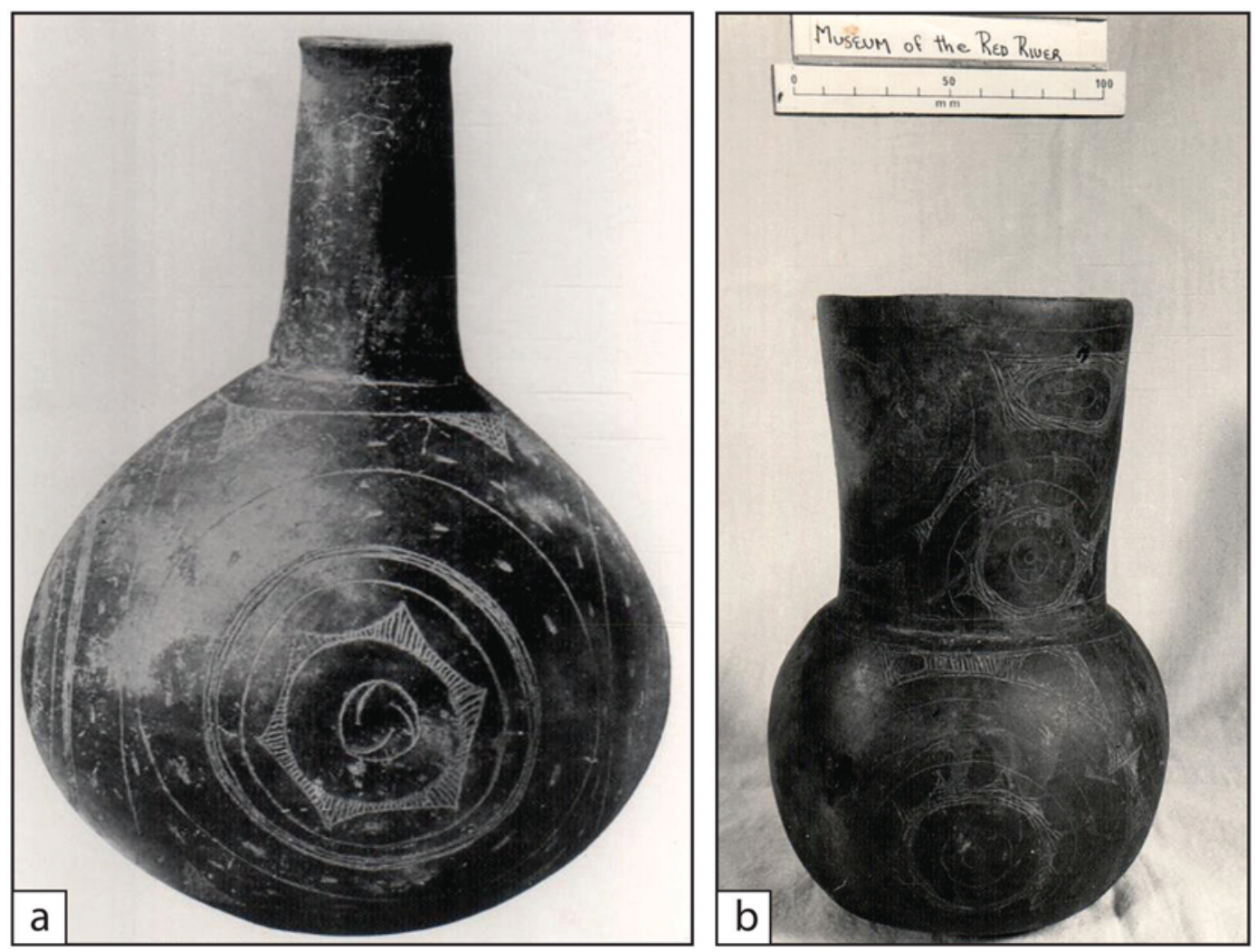

Figure 3. Examples of the Rayed Circle Burst motif (a) a bottle from the McClure Place (3MI29), AAS\# 772380; (b) a bottle from the Bowman site (3LR50), AAS\# 775335. Images used with the permission of the Arkansas Archeological Survey.

There are variations to the overall theme. For example, a bottle from Battle Mound contains the simplest representation composed of a single burst with no additional elements within the burst (see Figure 2a). A bottle from Cryer Field (3LA35) has a rayed circle burst with a separate unembellished circle within the burst element (Figure 2b). A vessel from Mineral Springs has a rayed circle burst with larger triangles that are less rotational with a separate single small circle within the burst element (Figure 2c). Additional variations include bottles from the McClure (3MI29) and Bowman sites. A bottle from the McClure Place has an overall similar organization containing a rayed burst with concentric circles radiating outward (Figure 3a). However, the rayed circle burst is defined by emanating triangles organized hexagonally. Additionally, the vessel contains a second rayed circle motif (rayed circle overhead discussed below) around the neck. A bottle from the Bowman site has a more distinctive variation (Figure $3 \mathrm{~b}$ ). The overall vessel form is more globular in form and has at least two, if not more, rayed circle burst elements on both the body and the neck. In most examples, a series of concentric circles radiate outward from the central rayed circle burst. In some instances, the concentric circles contain additional tics or bursts, whereas in others they are not included.

The rayed circle burst motif has been identified on 85 whole vessels within the current corpus. The 85 rayed circle burst vessels are all from sites containing Middle and Late Caddo (ca. A.D. 1200-1600) components, although many of the sites have not been studied fully to more distinctly understand their temporal components and the context of vessels within site intra-organization and affiliation.

\section{Rayed Circle Overhead Motif}

A second rayed circle motif variation, as defined herein, is termed the rayed circle overhead motif. This naming convention is associated with the location of the motif on vessels. There are 65 representations of the overhead motif in the current corpus. As with the rayed circle burst motif, all are (tentatively) associated with Middle and Late Caddo period sites. 
The defining criterion of the motif is a series of triangles, often filled with engraved cross-hatching, and located at the base of the neck (Figure 4). The triangles are pointed downward in a fairly symmetrical organization and connected at the base of the triangles by a single circular engraving often with an accompanying set of nested concentric circles. The design organization is best viewed from overhead rather than in profile, as the naming convention illustrates. This distinction offers consideration that the visual perspective of the rayed circle overhead motif is as the bottle is being used rather than in profile, although this could simply be a result of the vessel shape and an artistic adaptation to commonly understood themes and associated meanings (see Gadus 2013). Since the bottle vessel form was likely used for storing and pouring liquids into other vessels (such as bowls) or drinking from directly, it is suggested that the bottle orifice is an important central element such that the liquid within the bottle "literally gushes forth" through a symbolic portal (Reilly 2004:130).
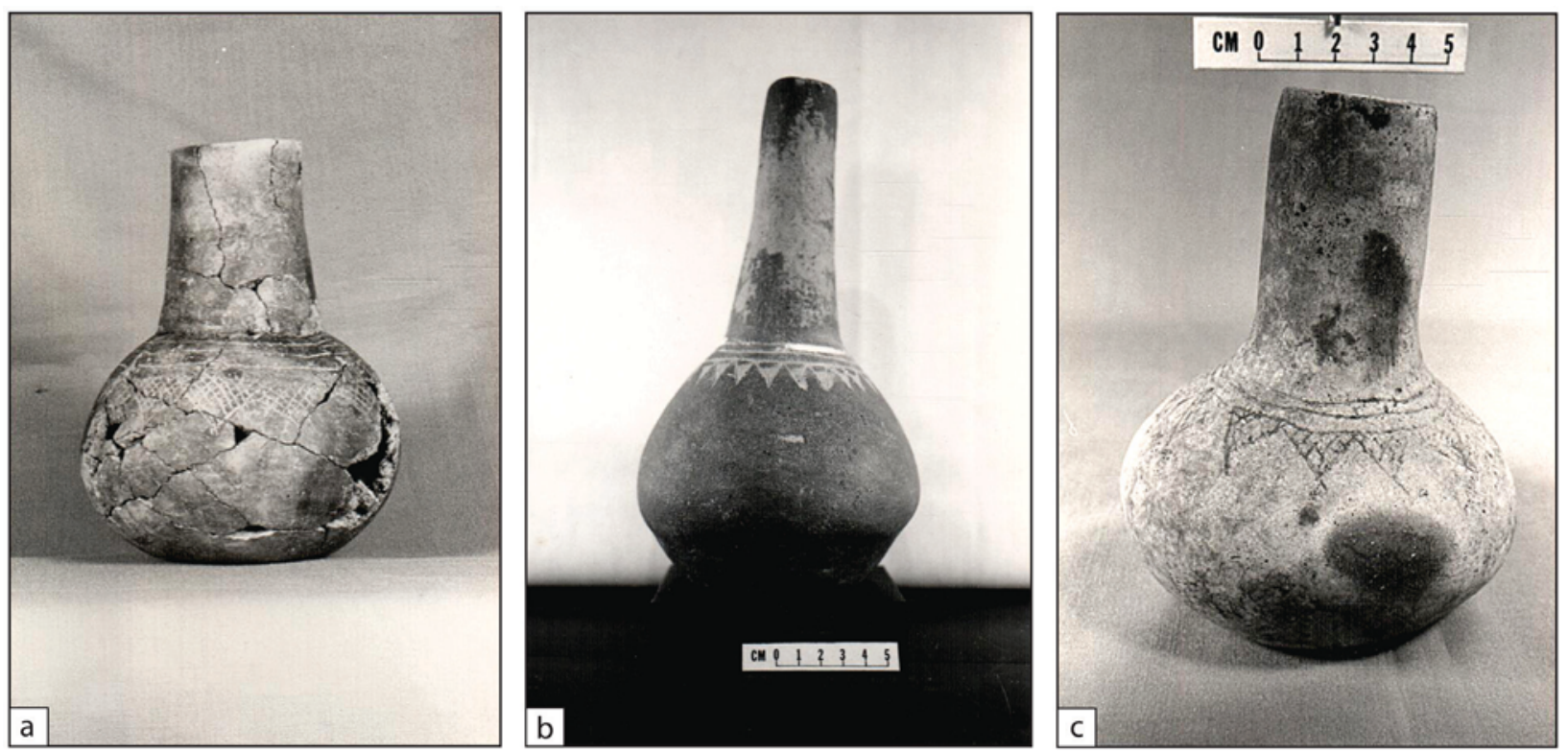

Figure 4. Examples of the Rayed Circle Overhead motif on bottles (a) a bottle from Ferguson (3HE63), AAS\# 734671; (b) a bottle from Arnold Mound (3CL67), AAS\# 714079; (c) a bottle from the Jim Keith site (3C04), AAS\# 712361 (see also McKinnon and Brandon 2014). Images used with the permission of the Arkansas Archeological Survey.

\section{Rayed Circle Overhead Motif and Vessel Form}

Whereas the rayed circle burst motif is primarily restricted to bottles within the current database, about half of vessel forms that contain the rayed circle overhead motif are bottles and the remaining are bowls (Figure 5). The rayed circle overhead motif on bowls is almost identical to representations on bottles. The bowls contain a series of triangles filled with engraved cross-hatching and are pointed downward from a circular engraving often with an accompanying set of nested concentric circles. However, as a result of the bowl form, the overhead motif is not fully visible from overhead. The interchangeable design elements on different vessel forms suggest a functional, perhaps symbolic, relationship or common identifier between the bottles and bowls. In other words, might the bowls represent the container in which the liquid from the bottles was poured into? Do they form a set? 

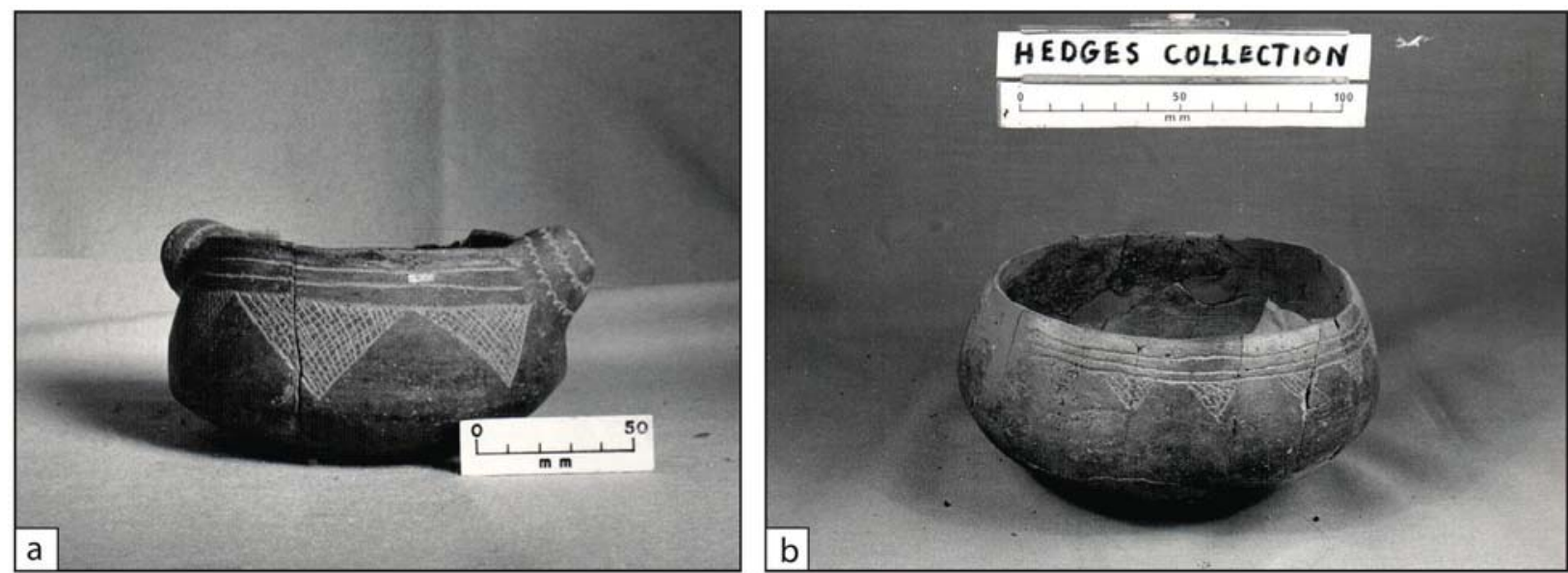

Figure 5. Examples of the Rayed Circle Overhead motif on bowls (a) a bowl from Ferguson (3HE63), AAS\# 824442; (b) a bowl from Cooks East (3HS106), AAS\# 773125. Images used with the permission of the Arkansas Archeological Survey.

\section{Rayed Circle Motif Distribution}

In order to examine the distribution and relationship of the two suggested rayed circle motif varieties across space, a GIS was utilized where site coordinates allows for ceramics to be situated across the Caddo landscape. When examined spatially, some preliminary patterns are realized that can be more fully evaluated as additional ceramics continue to be included in the database.

\section{Rayed Circle Burst Motif}

Vessels with the rayed circle burst motif have been found at sites located along major rivers and tributaries, including Red River, Caddo River, Little Missouri River and tributaries, Antoine River, Mine Creek as a tributary to the Little River, Ozan Creek drainage in Hempstead County, a single vessel along the Lower Ouachita in Union County (Boyt's Field), and a single vessel along the Sulphur River (Old Moore Place) in Texas (Figure 6). A simple distribution analysis reveals that rayed circle burst vessels are clustered primarily in two areas: (1) along the Red River in southwest Arkansas (Cluster 1) and (2) northeast of the Red River along the Caddo, Little Missouri, Saline tributary, and Ozan Creek drainage in south-central Arkansas (Cluster 2). Forty-one (48 percent) rayed circle motif vessels are located within Cluster 1 and 32 (38 percent) are located in Cluster 2. In terms of the number of sites represented, eight sites in Cluster 1 contain rayed circle burst vessels whereas 13 sites in Cluster 2 are represented. Cluster 1 contains a greater number of rayed circle burst vessels yet they exist in more concentrated occurrences at less sites. For example, the total number of vessels found at Battle Mound and Haley Place constitutes 49 percent of the vessels in Cluster 1 and 25 percent of the entire rayed circle burst corpus.

The concentration of rayed circle burst vessels in Cluster 1 can be further evaluated using a standard distance statistical algorithm. The 2-standard deviation distance analysis reveals a distributional radial distance of approximately $45 \mathrm{~km}$ (see Figure 6). This preliminary analysis also reveals the location of sites outside the initial 2-standard deviation distance analysis and external to the two proposed cluster areas (using the current corpus). They include vessels from Robinson Mound (3CL30) on the Caddo River, Boyt's Field (3UN13) in Union County along the Lower Ouachita, the Belcher site further south on the Red River, and Old Moore Place (41CS5) along the Sulphur River in northeast Texas. The Bowman site, although located within the statistical area, is included with this group because it is situated some distance upriver from Cluster 1. Initial observations show that the Belcher site, with its locational relationship to sites further upstream, has a bottle with the primary rayed circle burst motif that is almost identical to a bottle from Battle Mound (see Figure 2a). 


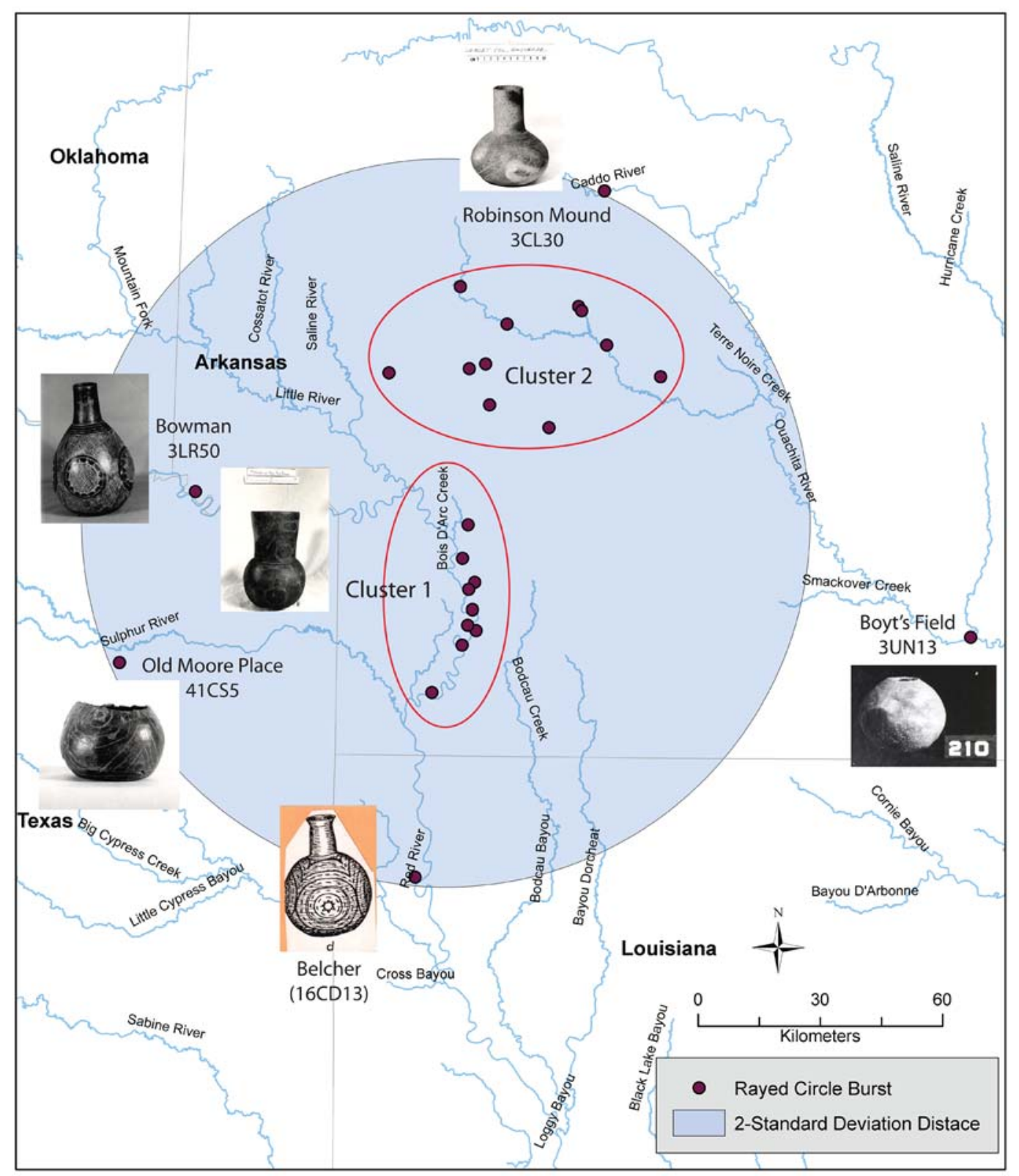

Figure 6. Distribution of the Rayed Circle Burst motif with results from a 2-standard deviation distance analysis. Outliers are shown as images of vessels. Images of outlier vessels used with the permission of the Arkansas Archeological Survey.

\section{Rayed Circle Overhead Motif}

The distribution of the rayed circle overhead motif is much more dispersed than the clustered rayed circle burst motif occurrences (Figure 7). There are no visible clusters and the motif is well represented throughout the major rivers and associated tributaries, although occurrences are more prevalent at sites northeast of the Red River along the Caddo, Little Missouri, Ouachita, Saline tributary, and Ozan Creek drainage in southeast-central Arkansas. Using a standard distance spatial statistical algorithm reveals a distributional radial distance of approximately $50 \mathrm{~km}$ (see Figure 7). The majority of sites are within the 2 -standard deviation distance and consistent with the broadly distributed corpus and lack of cluster areas. Using the current database, the Noble Lake (3JE19) site in Jefferson County is shown outside the 2-standard deviation and situated along the Arkansas River. The Poole (3GA3) site is located in Garland County along the Upper Ouachita River and on the edge of the statistical boundary (Wood 1981). 


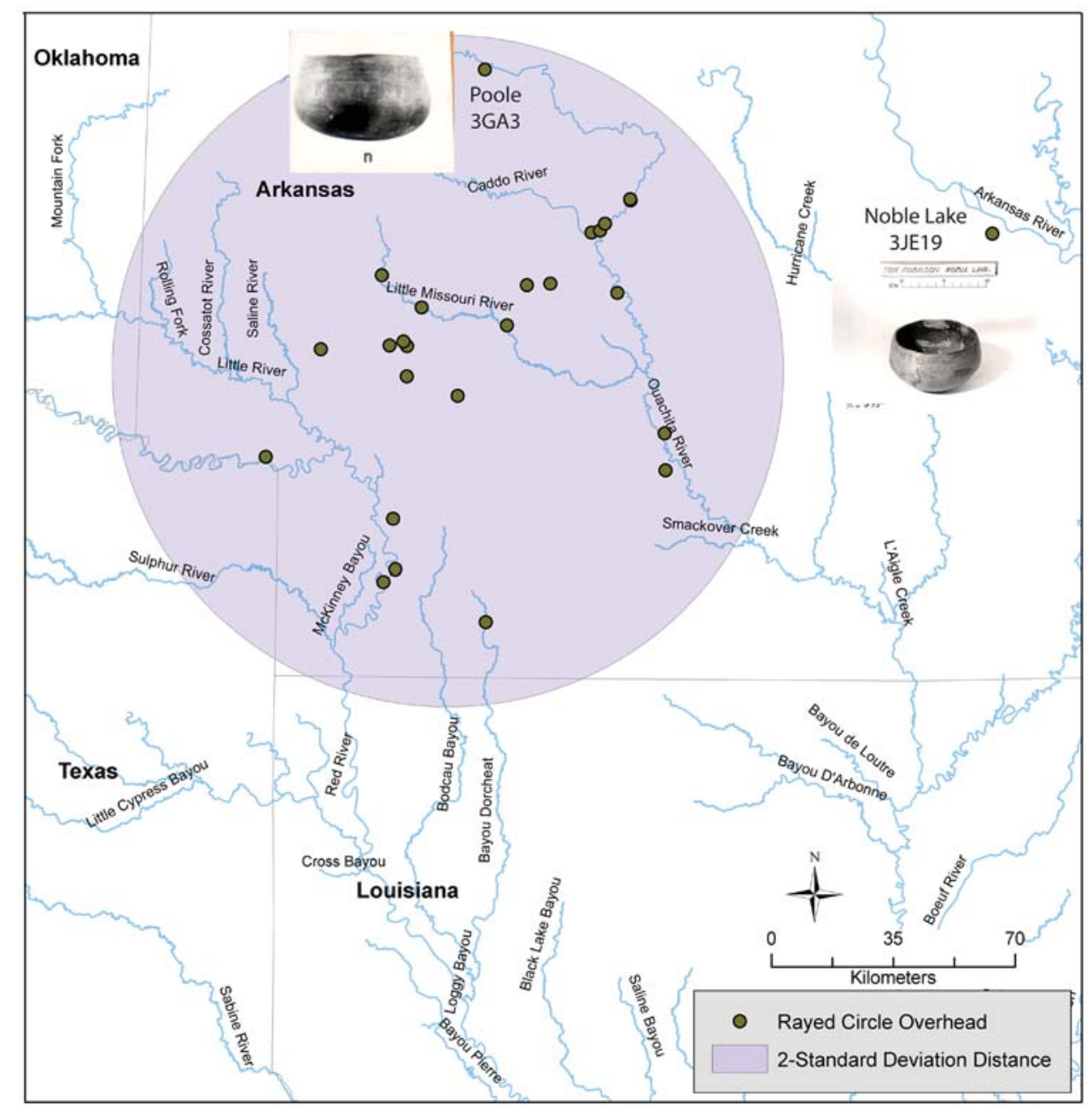

Figure 7. Distribution of the Rayed Circle Overhead motif with results from a 2-standard deviation distance analysis. Outliers are shown as images of vessels. Images of outlier vessels used with the permission of the Arkansas Archeological Survey.

Unlike the variation in design that is apparent in the initial rayed circle burst outliers, the rayed circle overhead outliers at the Noble Lake and Poole sites are identical in design to those within the 2-standard deviation distance. The Noble Lake site is part of the Menard Complex (A.D. 1400 - 1700) as a series of sites situated along the lower Arkansas River and at the confluence of the Mississippi (House 1995). This Noble Lake vessel was originally documented as "anomalous" (House 1995:Figure 39), although surface collections and excavated material contain some recognizable Caddo styles that demonstrate "evidence of [Menard Complex] interaction with the Caddoan area" (House 1995:90; see also House 1997; Walker 2014). The second outlier is at the Poole site where archaeological investigations document a long history of Fourche Maline and Caddo occupations (Wood 1981). Tangential to this case study, but interesting enough to highlight, is the observation made by Wood of a single "seed jar" found at the Poole site (Upper Ouachita) and common in the Middle Ouachita region (Wood 1981:57). I diverge on this because a Caddo style "seed jar" was also found at the Noble Lake site (Arkansas Archeological Survey, Fayetteville, Arkansas [AAS], Site file [SF] 3LJE19).

\section{Rayed Circle Burst and Overhead Motif Relationships}

When the distribution of the two motifs are overlain and examined across space, an interesting spatial patterning is observable (Figure 8). The combination of motifs reveals a possible corridor of sites in the proximity of Little Missouri, Ozan Drainage, and Caruse Creek. Initial observations hint at cultural 
dispersal of the rayed circle overhead motif from the northeast and the rayed circle burst motif from the southwest, with the combination of both representations situated at sites of regional influence and exchange in the corridor between. Sites containing both motifs within this corridor include Murf Davis (3PI13), Stokes Mound (3PI17), and Hayes Mound along the Little Missouri drainage, Mineral Springs, Flowers, Jim Cole (3HE59), and Washington Mound along the Ozan Creek drainage, and Ferguson along Caruse Creek. The Lester (3LA38) and Battle Mound sites along the Red River also contain both motif varieties. While preliminary observations are clearly tentative based on the vessels included in the database thus far, the presence of both motifs at a few sites between the Ouachita River and Red River drainages is interesting and will require further analysis. Initially, the distributional analysis does not support the suggestion, as noted above, that the two motifs (and associated ceramic forms) represent an understood set with shared meanings and usages. In other words, the two are not represented equally at sites throughout the Caddo area. Yet, when considering biases in collection and current database, if these two motifs indeed represent a ceramic set then why is this combination limited to the possible corridor?

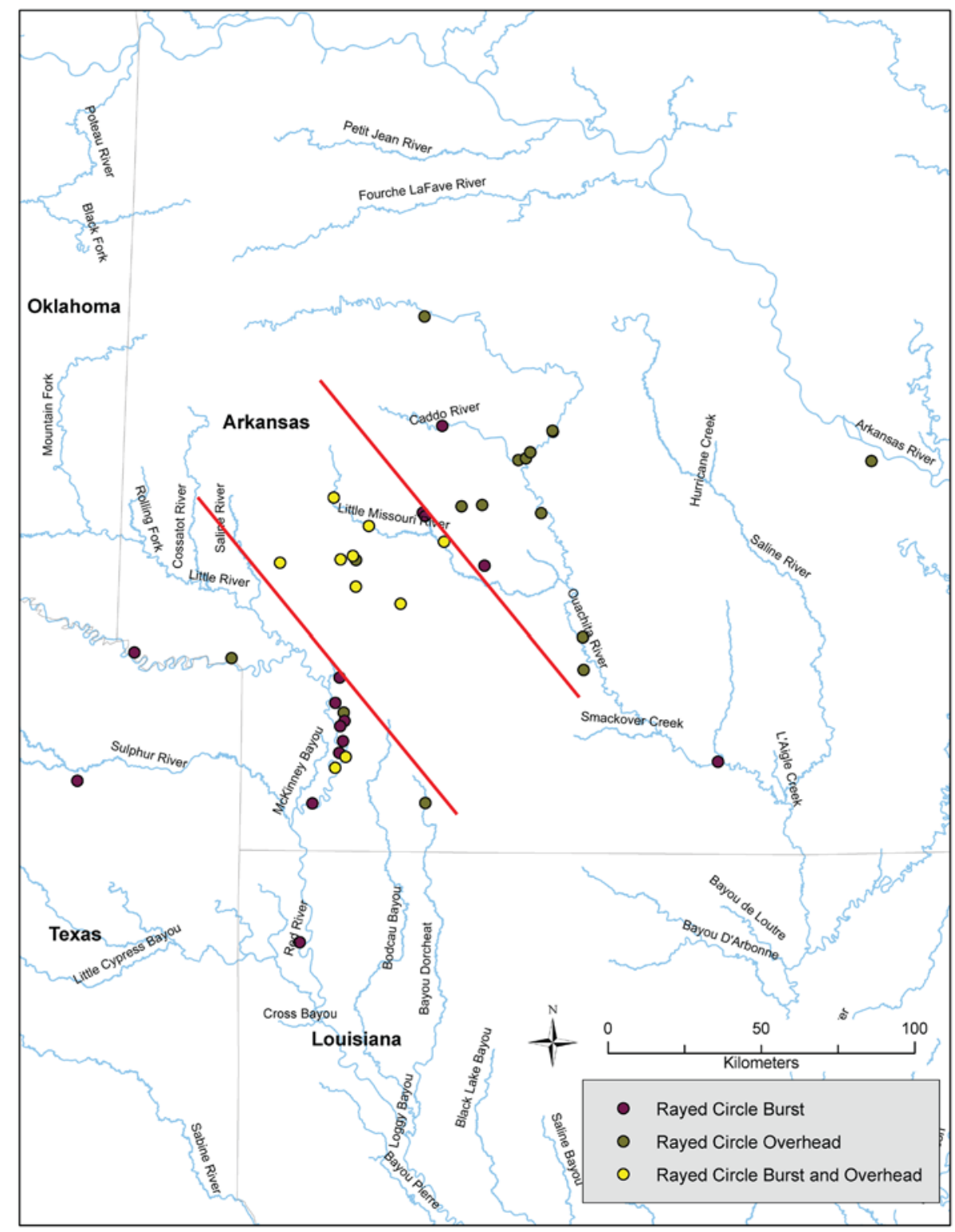

Figure 8. Distribution of both Rayed Circle Burst and Rayed Circle Overhead motifs and their spatial relationships. Note the possible corridor of sites in the proximity of Little Missouri, Ozan Drainage, and Caruse Creek. 


\section{Closing Statement}

This second GIS case study offers some points to explore and refine with regard to spatial relationships of proposed rayed circle motif variations across the Caddo landscape. As research and evaluation continues and evolves, a primary concern in this initial phase is the broad nature of the temporal information with many sites lacking the much needed absolute dating to firmly organize their occupational history into a cultural landscape chronology. In order to examine cultural distribution of design and associated ideological influences, a more specific chronology will need to be developed. This will be challenging, but potentially feasible, since many of the vessels do not contain intrasite provenience and are restricted to broader relative dating techniques.

A second concern is the somewhat subjective and biased nature of the ceramic corpus. For example, the limited two-dimensional visibility of the vessels with the use of photographs prohibits an analysis of the entire vessel design. Furthermore, the current corpus is developed from incomplete or selective data gathered by collectors. The need to broaden the database to include vessels in publications as well as adjoining states is an important next step. The inclusion of vessels from east Texas and northeast Arkansas will greatly elucidate suppositions about cultural dispersal and influences related to the possible corridor that this initial case study suggests.

These two concerns are noteworthy and important to consider moving forward. Nonetheless, this case study demonstrates the value of spatial analysis to visualize cultural patterns. Results can be dynamically examined and integrated into other spatial layers, questions proposed, and analyses refined as additional data are included and re-evaluated. In this instance, initial observations offer visual considerations of influence and exchange at sites in Arkansas, where the rayed circle motif is present. These observations suggest a possible distinction of motif use and expression that can be tested further. As is the nature of scientific research, results often propose more questions than answers. This is a good thing. These results provide a framework to ask more specific questions, not only about the material objects themselves, but also about "how people create worlds for themselves and how these change overtime" in the context of "the lived experience of place" across a broad cultural landscape (Gosden 1999:153).

\section{Acknowledgements}

Thanks to the contribution of many individuals, including Dr. Ann Early, her students and employees from Henderson State University, including (the now) Drs. Mary Kay Sandford and David B. Kelley, Arkansas Archeological Survey photographer Dan Printup, University of Arkansas Museum photographer Mary McGimsey, Dr. Frank Schambach, and many others for taking all the photographs of vessels. Two anonymous reviewers provided valuable comments and suggestions to this paper. An original version of this report was presented at the 2013 meeting of the Arkansas Archeological Society held in Conway, Arkansas.

\section{References Cited}

Allen, Kathleen M.S., Stanton W. Green, and Ezra B.W. Zubrow

1990 Interpreting Space: GIS and Archaeology. Taylor \& Francis.

Anselin, Luc

2005 Spatial Statistical Modeling in a GIS Environment. In GIS, Spatial Analysis, and Modeling, edited by David J. Maguire, Michael Batty, and Michael F. Goodchild, pp. 93-112. ESRI Press, Redlands, California.

Banning, E.B.

2002 Archaeological Survey. Plenum Publishers, New York. 
Bohannon, Charles F.

1973 Excavations at the Mineral Springs Site, Howard County, Arkansas. Research Series No. 5. Arkansas Archeological Society, Fayetteville.

Brooks, Robert L.

2012 Decisions in Landscape Setting Selection of the Prehistoric Caddo of Southeastern Oklahoma: A GIS Analysis. In The Archaeology of the Caddo, edited by Timothy K. Perttula and Chester P. Walker, pp. 335-362. University of Nebraska Press.

Dunnell, Robert C., and Dancey, William S.

1983 The Siteless Survey: A Regional Scale Data Collection Strategy. In Advances in Archaeological Method and Theory Vol. 6, pp. 267-287.

Early, Ann M.

1986 Dr. Thomas L. Hodges and His Contributions to Arkansas Archeology. The Arkansas Archeologist 23/24:1-11.

2002 The East Phase. Field Notes: Newsletter of the Arkansas Archeological Society 304:4-8.

Gadus, Eloise Frances

2013 Twisted Serpents and Fierce Birds: Structural Variation in Caddo Engraved Ceramic Bottle Motifs. Bulletin of the Texas Archeological Society. 84:213-246.

Gregory, Hiram F.

1980 The Doctor and Caddology: Dr. Clarence H. Webb's Contribution to Caddo Archaeology. Louisiana Archaeology 6:19-28.

Genton, Marc G.

2001 Robustness Problems in the Analysis of Spatial Data. In Spatial Statistics: Methodological Aspects and Applications, edited by Marc Moore, pp. 21-37. Springer-Verlag Publishing.

Girard, Jeffrey S., Timothy K. Perttula, and Mary Beth Trubitt

2014 Caddo Connections: Cultural Interactions within and Beyond the Caddo World. Rowman \& Littlefield Publishers.

Gosden, Chris

1999 Anthropology \& Archaeology: A Changing Relationship. Routledge, London.

Harrington, Mark R.

1920 Certain Caddo Sites in Arkansas. Indian Notes and Monographs, Miscellaneous Series No. 10. Museum of the American Indian, Heye Foundation, New York.

Hodder, Ian and Clive Orton

1979 Spatial Analysis in Archaeology. Cambridge University Press.

Hoffman, Michael

1970 Archaeological and Historical Assessment of the Red River Basin in Arkansas. In Archeological and Historical Resources of the Red River Basin, edited by Hester A. Davis, pp. 137-194. Research Series No. 1. Arkansas Archeological Survey, Fayetteville.

House, John

1995 Noble Lake: A Protohistoric Archeological Site on the Lower Arkansas River. The Arkansas Archeologist 36:47-97.

1997 Time, People and Material Culture at the Kuykendall Brake Archeological Site, Pulaski County Arkansas. Paper presented at the Southeastern Archaeological Conference, Baton Rouge, Louisiana. 
Jones, Andrew

2002 Archaeological Theory and Scientific Practice. Cambridge University Press.

Kvamme, Kenneth L.

1999 Recent Directions and Developments in Geographical Information Systems. Journal of Archaeological Research 7:153-201.

2007 Integrating Multiple Geophysical Datasets. In Remote Sensing in Archaeology, edited by James Wiseman, and Farouk El-Baz, pp. 345-374. Springer.

Lockhart, Jami J.

2007 Prehistoric Caddo of Arkansas: A Multiscalar Examination of Past Cultural Landscapes. PhD dissertation. Environmental Dynamics. University of Arkansas, Fayetteville.

2010 Tom Jones (3HE40): Geophysical Survey and Spatial Organization at a Caddo Ceremonial Mound Site in the Uplands of the West Gulf Coastal Plain of Arkansas. Southeastern Archaeology 29(2):236-249.

2012 Spatial Patterns of Caddo Mound Sites in the West Gulf Coastal Plain of Arkansas. In The Archaeology of the Caddo, edited by Timothy K. Perttula and Chester P. Walker, pp. 313-334. University of Nebraska Press.

Maguire, David J.

2005 Towards a GIS Platform for Spatial Analysis and Modeling. In GIS, Spatial Analysis, and Modeling, edited by David J. Maguire, Michael Batty, and Michael F. Goodchild, pp. 19-40. ESRI Press, Redlands, California.

McKinnon, Duncan P.

2011 Foster Trailed-Incised: A GIS-Based Analysis of Caddo Ceramic Distribution. Caddo Archeology Journal 21:71-88.

2015 Zoomorphic Effigy Pendants: An Examination of Style, Medium, and Distribution in the Caddo Homeland. Southeastern Archaeology 34(2):116-135.

McKinnon, Duncan P., and Jamie C. Brandon

2014 Sometimes Things Just Happen: A Small Hempstead Engraved Bottle Finds a Site. Field Notes: Newsletter of the Arkansas Archeological Society 378:10-11.

Moore, Clarence B.

1912 Some Aboriginal Sites on the Red River. Journal of Academy of Natural Sciences of Philadelphia 14:481638.

Neubauer, Wolfgang

2004 GIS in Archaeology - the Interface between Prospection and Excavation. Archaeological Prospection 11:159-166.

Perttula, Timothy K.

1992 "The Caddo Nation": Archaeological and Ethnohistoric Perspectives. University of Texas Press, Austin.

2012 The Archaeology of the Caddo in Southwest Arkansas, Northwest Louisiana, Eastern Oklahoma, and East Texas: An Introduction to the Volume. In The Archaeology of the Caddo, edited by T. K. Perttula and C. P. Walker, pp. 1-25. University of Nebraska Press, Lincoln.

Perttula, Timothy K., Ann M. Early, Louis E. Albert, and Jeffrey Girard (compilers and editors), with contributions by Robert L. Brooks, Scott W. Hammerstedt, Shawn Marceaux, Duncan McKinnon, Robert Z. Selden, Jr., Mary Beth Trubitt, and Mark Walters

2013 Caddo Bibliography: Archaeology and Bioarchaeology, Ethnohistory and Ethnography, and History, $4^{\text {th }}$ Edition. Special Publication No. 25. Friends of Northeast Texas Archaeology, Pittsburg and Austin. 
Phillips, Philip and James A. Brown

1978 Pre-Columbian Shell Engravings from the Craig Mound at Spiro, Oklahoma. Volume 1, Cambridge, Peabody Museum Press

Reilly, F. Kent, III

2004 People of the Earth, People of the Sky: Visualizing the Sacred in Native American Art of the Mississippian Period. In Hero, Hawk, and Open Hand, edited by Richard F. Townsend. pp. 125-138. Yale University Press.

Schambach, Frank F., and John E. Miller, III

1984 A Description and Analysis of the Ceramics. In Cedar Grove: An Interdisciplinary Investigation of a Late Caddo Farmstead in the Red River Valley, edited by Neal L. Trubowitz, pp. 109-170. Research Series No. 23. Arkansas Archeological Survey, Fayetteville.

Shekhar, Shashi, Chang-Tien Lu, and Pusheng Zhang

2003 A Unified Approach to Detecting Spatial Outliers. GeoInformatica 7(2):139-166.

Suhm, Dee Ann, Alex D. Krieger, and Edward B. Jelks

1954 An Introductory Handbook of Texas Archaeology. Bulletin of the Texas Archeological and Paleontological Society 25:144-227.

Vogel, Gregory

2012 Viewshed Characteristics of Caddo Mounds in the Arkansas Basin. In The Archaeology of the Caddo, edited by Timothy K. Perttula and Chester P. Walker, pp. 139-176. University of Nebraska Press.

Walker, Leslie

2014 Liminal River: Art, Agency, and Cultural Transformation Along the Protohistoric Arkansas River. PhD dissertation, Department of Anthropology, University of Arkansas.

Weber, J. Cynthia

1971 The Hays Mound: A Very Preliminary Report. Arkansas Archeological Society Field Notes 76:3-6.

Webb, Clarence H.

1959 The Belcher Mound: A Stratified Caddoan Site in Caddo Parish, Louisiana. Memoir 16. Society for American Archaeology, Salt Lake City.

Weinstein, Richard A., David B. Kelley, and Joe W. Saunders (editors)

2003 The Louisiana and Arkansas Expeditions of Clarence Bloomfield Moore. University of Alabama Press, Tuscaloosa.

Wheatley, David, and Gillings, Mark

2002 Spatial Technology and Archaeology: The Archaeological Applications of GIS. Taylor and Frances, London.

Williams, Jeffrey M.

2007 GIS Aided Archaeological Research of El Camino Real de Los Tejas with Focus on the Landscape and River Crossings along El Camino Carretera. Master of Spatial Science, Stephen F. Austin State University, Nacogdoches, Texas.

Wood, W. Raymond

1981 The Poole Site, 3GA3, With New Foreword and Summary by Ann M. Early. The Arkansas Archeologist 22:7-65. 